\title{
The Chinese from Indonesia in the Netherlands and their heritage Chinese Indonesian Heritage Center (CIHC)
}

\author{
PATRICIA TJIOOK-LIEM
}

\begin{abstract}
Chinese from Indonesia in the Netherlands are (post)colonial migrants who share a long historical tie with the Dutch. In this article the author brings together and focuses on three interconnected subjects: Chinese from Indonesia in the Netherlands; the historical development and present meaning of "heritage"; and the Chinese Indonesian Heritage Center (CIHC). For her research on the Chinese Indonesians in the Netherlands, the author has used the literature available on this minority group. The scarce specific data for this group are part of the explanation of its "invisibility" in society and research, and of the difficulty in quantifying them. The development of heritage as a western concept has led her to the question of what heritage might mean for migrants in their new homeland. The concluding part on the Chinese Indonesian Heritage Center introduces the activities of the Center designed to achieve her goals which are focused on the history of this group.

KeYwords

Peranakan-Chinese; Indonesia; the Netherlands; (post)colonial migrants; heritage.
\end{abstract}

Chinese from Indonesia and their heritage have only recently attracted interest in the Netherlands. Interest began to grow in 2011 when the scientific research center KITLV (Koninklijk Instituut voor Taal-, Land- en Volkenkunde) in

PATRICIA TJIOOK-LIEM, affiliated fellow of the KITLV attached to the Chinese Indonesian Heritage Center (CIHC) in Leiden and has been involved with it since its inception in 2011. Her PhD research concerned the legal position of the Chinese in the Dutch East Indies and the colonial government's legislation policy towards this minority group in the period 1848-1942. Her present research interest is on the Peranakan Chinese and their postcolonial migration to the Netherlands. Her publications include: "Feiten en ficties bij het ontstaan van de Japannerwet (1899)", Rechtskundig Magazijn Themis 2005: 192-208, De rechtspositie der Chinezen in NederlandsIndië 1848-1942 (Leiden University Press, 2009), and "The Loa Joe Djin-case, A trigger to change", in: Marleen Dieleman, Juliette Koning, and Peter Post (eds), Chinese Indonesians and regime change, pp. 117-138 (Leiden: Brill, 2011). Patricia Tjiook-Liem can be contacted at: patricia. tjiook.liem@gmail.com.

(C) 2017 Faculty of Humanities, Universitas Indonesia

PATRICIA TJIOOK-LIEM| DOI: 10.17510/wacana.v18i1.571 . 
Leiden initiated the Chinese Indonesian Heritage Center (CIHC, www. cihc.nl). ${ }^{1}$ The primary goal of the CIHC is to collect and safeguard heritage material of the Chinese from Indonesia living in the Netherlands, before it is lost forever. The KITLV was thought to be the appropriate institution for this objective. Founded in 1851 to acquire and preserve knowledge of the Dutch overseas territories, it is now a scientific research institute associated with the Royal Netherlands Academy of Arts and Sciences (Koninklijke Nederlandse Akademie van Wetenschappen/KNAW). Today the KITLV's research projects focus on Southeast Asia, Indonesia in particular, and the "Dutch" Caribbean. The establishment of the CIHC for the purpose of preserving the heritage of the Chinese from Indonesia was a unique and important step, creating a singular opportunity to collect material which might contribute to research and to the preservation of their history.

Pivotal in the initiative to establish the CIHC was the realization that in the past few decades any attention paid to the Chinese from Indonesia has been structurally absent, both from the government and from the research community. In contrast to the attention the authorities in the Netherlands have shown in other colonial and non-colonial groups of immigrants, for whom the government has developed policies to regulate their socio-economic position or made provisions for the benefit of their culture and history, such measures have been non-existent for the Chinese from Indonesia. This gives grounds to claim that there is a real lack of knowledge about this population group. Was their size too small and their history too insignificant? Have they never been of any importance in Dutch colonial, postcolonial and migration history? Does the group have insufficient obvious and serious problems to be noticed by the Dutch community, government, and research institutes? In the literature they are sometimes referred to as "invisible migrants" (Oostindie in Bosma, Lucassen, and Oostindie 2012: 103) or as "initiated outsiders" (Oostindie 2010: 29).

A small number of researchers has been engaged in research on this particular group, but in general, there is barely any reference to these Chinese in the literature dealing with repatriates and migrants from the former colonies. Their invisibility in Dutch society is all the more remarkable since, at times during the colonial period the Chinese population was actually the object of great attention and was even regarded as a problem. Their community was censured as the "Chinese problem", a stigma which subsequently came back to haunt them and continued to do so even after the independence of Indonesia, when (alleged) difficulties were often referred to as "masalah Cina". Perception and stereotyping were highly influential factors in the colonial policy and were even carried over to the anti-Chinese and discriminatory political climate in Indonesia after 1945. At times, they were an important reason for a number of Chinese to choose to leave Indonesia.

In the Netherlands, the group has always sought to be inconspicuous. As well-educated, Dutch-speaking (post)colonial migrants and as a minority,

1 Thanks to Swanny Thee for translating the original article in English. 
their socio-economic integration in the Netherlands was considered highly successful. In this achievement they might have benefited from what Oostindie calls the "postcolonial bonus". ${ }^{2}$ Certainly they rarely feature in debates about minorities. Although they regard themselves as a group, they have never tried to profile themselves as such (Oostindie 2010: 28-29, 45-46).

They do not seem to suffer from this invisibility, appearing to prefer to be left alone, to keep a "low-profile", thereby avoiding drawing attention to themselves, and keeping the history of their life before their migration to the Netherlands a closed book. This reticence has also extended to their families, where the silence about a past and at times painful period has often meant that their offspring had very little or no knowledge at all of their (grand) parents' history or of the factors underlying the choices they had to make. As an inevitable consequence, the younger generations have turned more and more to the Dutch culture for their identification.

The KITLV's initiative shows that there is now a growing interest in and that more specific attention is being paid to the group from within the scientific community. This attention has been met with surprise by the group of Chinese from Indonesia who, however, have responded quite positively, as is reflected in their great interest in CIHC activities in recent years. It is not merely a (re)discovery of one's own history or of the history of the group. Even more important might be the realization that this history deserves to be paid attention to and is worth recording and being passed on, for example, by preserving its members' own heritage materials.

Three concepts are interconnected in the title of this article and will be discussed in the following order: the Chinese from Indonesia; the concept of heritage; and the Chinese Indonesian Heritage Center. Our first step is to take the Chinese from Indonesia out of the shadows, put them in the context of Dutch history and "find" them in the existing literature published by researchers and government institutions. Having done so, we shall address the development, the concept and significance of heritage, past and present. The goals and activities of the Chinese Indonesian Heritage Center (CIHC) will form the closing part.

The literature refers to Chinese from Indonesia as Indo-Chinese or Peranakan Chinese. In this article we shall use the terms Peranakan(s) or Peranakan Chinese. The term Peranakan contains the word anak, meaning 'child', indicating that Peranakans are children of their country of birth, Indonesia. Among the characteristics of the Peranakans is their self-image of being a mix of three cultures: Chinese, consistent with the origin of their

2 The term "postcolonial bonus" was coined by Oostindie and refers to Dutch citizenship allowed on political grounds to migrants from the Dutch East Indies/Indonesia, Suriname, and the Antilles. These migrants could claim Dutch citizenship, which migrants from elsewhere could not, or only with difficulty. This citizenship on political grounds included the right to settle and live in the Netherlands and was in many cases extended to citizens from former colonies who no (longer) had a formal right to it. The postcolonial bonus was of broader significance since postcolonial migrants were able to pull other more direct advantages, such as their social and cultural capital, out of their colonial baggage (Oostindie 2010: 45-46). 
ancestors; Indonesian, according to their country of birth; and Dutch, in line with the culture they feel connected to by education. In their own perception, there are no clear boundaries between these three cultures; they blend smoothly, and each person makes his/her own choice to what extent the one culture prevails over the other.

\section{Peranakan Chinese And the Dutch: a brief outline of A lONG Historical CONNECTION}

For the great majority of people in the Netherlands, the Chinese from Indonesia are relatively unknown. People might know them personally as their family doctor or as a medical specialist, dentist, engineer, economist, or as a colleague, while some Peranakans are known in the arts and sciences, or as the owner of an Indonesian toko. Their background, history, and long historical ties with the Netherlands are practically terra incognita. For Dutch people it is difficult to distinguish them from other Chinese.

Although various groups of Chinese descent can be found in the Netherlands, generally speaking there is only one label to indicate them as one group: "Chinese". However, they form a heterogeneous population with sometimes large contrasts, attributable to the differences in country of origin, language or dialect, time of arrival, motives for settling in the Netherlands and their (un-)familiarity with the Netherlands and Dutch culture. Whether they have or have not come from the former Dutch colonies is, in our view, another important distinction. An origin in former Dutch colonies often means a long historical tie which is very characteristic of the Chinese from Indonesia.

Despite of this long and shared previous history, it is not the Peranakan Chinese who are highly visible in the Dutch community but the Chinese who do not have their roots in the colonies. Unquestionably, when the "Chinese in the Netherlands" are referred to, people almost immediately and exclusively think of the group of Chinese people who came to the Netherlands as seamen around 1911. Recruited by the Dutch merchant navy, they are known to have come to the Netherlands at that time to break the dock strike in Amsterdam and Rotterdam. These stokers and coal-trimmers - born in Guangdong, recruited and signed on in London - finally settled in Rotterdam-Katendrecht and Amsterdam-Binnen Bantammerstraat (Meeuwse 2000: 56-58). In these quarters, which have become known as Chinatown, they have focused their activities on the restaurant business. Over time, as the Dutch public grew familiar with Chinese restaurants, Chinese food became generally accepted. In 2000 Karina Meeuwse noted that, "the word 'Chinese' did not so much raise the association with members of a particular ethnic group as with rather well-established and accepted food" (Meeuwse 2000: 13). The strong presence of many Chinese (-Indies) restaurants across the Netherlands has made these Chinese much more visible in Dutch society. The commemoration of "One hundred years Chinese in the Netherlands" in 2011 was designed to celebrate this group of Chinese people, who came to the Netherlands from mainland China in 1911. 
The historical link of the Chinese people from the former colonies with the Netherlands goes much further back than 1911. For the scope of this article, which is exclusively concerned with the Chinese from the former Dutch East Indies colonies, we shall also disregard the Chinese people from the West Indies.

Contacts between the Chinese and the Dutch in the former Dutch East Indies date back to the early years of the Dutch East India Company (VOC/ Vereenigde Oostindische Compagnie). This business enterprise considered the Chinese people - who already had a longer presence in the Dutch East Indies - indispensable to its economic and administrative purposes. In the following centuries, the Chinese were somehow always present in Dutch colonial history, and, in once instance, were even embroiled in a catastrophic event, the gruesome Chinese massacre in Batavia in 1740. The essential links between the Dutch and the Chinese were trade and economy, in which the Chinese played a key intermediary role. Their role in colonial society and their culture had been taken into account in various ways, sometimes out of sheer necessity when it was considered that it would serve the interests of "the Indies", meaning the interests of the colonial government. The system of the Chinese officers, ${ }^{3}$ for instance, was a well-known colonial administrative system which began in the seventeenth century and lasted until the 1930s. As the importance of more knowledge about Chinese customs was soon recognized by the colonial government, in 1756 Pieter Haksteen, Secretary to the Bench of Aldermen of Batavia, and Oei Tsi Lauw, former Captain of the Chinese, were assigned to collect and collate Chinese family and inheritance law and customs. The result was the collected work "China's Law" (Chinaas regt 1761), a compendium which functioned as a guideline in the administration of justice in the colony (Tjiook-Liem 2009: 77, 157). After 1848, special regulations for the Chinese were laid down in the Netherlands-Indies legislation, an indication of their particular significance to the colonial government.

To suit the interests of Dutch commerce, the Chinese were equated with the Dutch in the field of commercial law in 1855. When in 1917 European family and inheritance law too was made applicable to the Chinese, this equation meant an equal legal position of the Chinese with Europeans on the entire field of European civil law. A few exceptions were made for certain customs which were deemed important and essential to Chinese culture. In 1917 it was not commercial or economic interest which ushered in such legal changes; it was political necessity which made such an equation necessary (Tjiook-Liem 2009: 215-216).

Until the end of the nineteenth century the position of the Chinese in colonial society had been principally determined by trade and economy. This changed around the turn of the twentieth century, when a period of

\footnotetext{
3 When Chinese community leaders were appointed, they were given the military titles of major, captain or lieutenant. However, their duties were not military, but mainly administrative. These functions were considered to be highly profitable and were highly sought after. This system ended around 1930.
} 
emancipation began for the Chinese. With their dedication in the first decade of the twentieth century to improving their legal position and their fighting for better education - known as the "Chinese Movement" (Fromberg 1911) they succeeded in achieving the establishment of Dutch schools for Chinese children (HCS, Hollands Chinese School) and also in attaining the abolition of most restrictive and grievous regulations in the following years. When a strong political consciousness awakened in the 1920s/1930s, three political currents developed, reflecting loyalties to and future expectations towards China, Indonesia, and the Netherlands.

Although contacts between Chinese and Dutch in the Dutch East Indies went back to the early years of the VOC, Dutch society in the Netherlands only saw Chinese from their East Indies colonies for the first time in the 1880s. As it happened, trade and economy were irrelevant in this meeting, as these contacts were of a completely different nature. Chinese students came to the Netherlands for further education or enrollment in academic studies. Education, especially Dutch education, has always been considered very important by Chinese parents. It was one of the essential conditions for social mobility as well as for the obtainment of a legal position equal to the Europeans. In the nineteenth century access to Dutch education in the Dutch East Indies was very limited for the Chinese youth, although not impossible for those from the upper class. In the pursuit of a good education for a better future in colonial society, Chinese parents turned to various forms of private Dutch education for their children. The striving and the strongly felt need for access to Dutch education for the Chinese were finally met by the colonial government with the establishments of the Dutch-Chinese schools (HCS) in 1908 , as is said above.

This is an appropriate moment to introduce two Chinese students who came in the Netherlands in the 1880s, whose movements, activities, and achievements were reported in Dutch and Dutch East Indies' newspapers at the time. One of the first students to go to the Netherlands in the nineteenth century was Tan Tjoen Liang from Buitenzorg (now Bogor), born in 1863. A scion of a prominent Chinese family - his father was a captain of the Chinese - he attended the King William III (Koning Willem-III) School in Batavia. The KW-III, as the school was popularly called, was an elite high school, to which only a few children from prominent and wealthy Indonesian and Chinese families had access in those days. The year following his graduation in 1883, Tan enrolled at the Technische Hogeschool (today the University of Technology) in Delft to study mechanical engineering. Tan Tjoen Liang was an active member of the Delft Student Union and, despite some delay (occasioned by his father's death which meant he had to return to the Netherlands Indies prematurely), he obtained his engineering degree in 1895. Around this time, his younger brother was also studying in the Netherlands. After his return to Indonesia, Tan was engaged in the management of the Tegal Waroe family 
estates, ${ }^{4}$ as director and co-owner. ${ }^{5}$

The other student who came in the Netherlands in the same period, was Oei Jan Lee, born in Banda Neira (Amboina) in 1863 as a son to a lieutenant of the Chinese. After attending the government primary school in Banda, Jan Lee received private education and training in Banda Neira and later at a private institute in Batavia, so that he would be properly prepared to sit the admission test for the HBS (Hogere Burgerschool, Dutch secondary school). He left the Indies for the Netherlands in 1882 and graduated from the gymnasium (alpha) ${ }^{6}$ in 1884. He then studied law in Leiden, where he obtained his doctorate in January 1889. He was back in the Dutch East Indies in 1892 and, at the age of 29 , was appointed attorney and counsellor at the Supreme Court of the Dutch East Indies, one of the highest posts in the colonial judiciary (Tjiook-Liem 2009: 276-277). This was an exceptional appointment and a lightning career at a time of large legal and social gaps between the Dutch (Europeans) and the Chinese (Foreign Orientals). Important official posts were rarely assigned to Chinese.

These two students can be considered the forerunners of a steady flow of students, beginning after the turn of the twentieth century and ending in the late fifties, only interrupted by World War II. The escalating conflict between the Netherlands and Indonesia in 1960 about the New Guinea issue, as well as other points of contention, led to a rupture in diplomatic relations between the two countries (Meijer 1994: 607), and it became impossible for students from Indonesia to enroll at schools and universities in the Netherlands.

Until World War II the majority of Indies Chinese who came in the Netherlands were students. Their life was in some measure coloured by the Chung Hwa Hui (CHH), a Chinese Students Union, founded in 1911. Especially established by and for Chinese students from the Dutch East Indies, the association became a central and regular meeting place for many. Apart from organizing social activities, the $\mathrm{CHH}$ would, if needed, make financial support available to Chinese fellow students. The $\mathrm{CHH}$ was also a platform for exchanging views on the political future, in which loyalty issues towards China, Indonesia, or the Netherlands were a recurring theme. University life was enjoyed intensely and smaller student associations emerged in other Dutch university towns (Van Galen 1989: 72-79). The circumstances of being far away from home and cut off from family ties and culture apparently created a great need to be together. These students were not exclusively involved in the Chung Hwa Hui, some also orientated themselves in Dutch society and joined Dutch fraternities. In the late fifties, when the influx of students drastically declined, the activities of the Chung Hwa Hui and other related student associations gradually petered out. The final dissolution of the Chung

4 De Tegal Waroe private estates, located east of Batavia, had rice-fields and a rice-husking factory.

5 Sumatra Post 13-4-1923; "Foto met verhaal" 17-3-2015 by Sioe Yao Kan: "Tan Tjoen Liang, de eerste Nederlands-Indische Chinese ingenieur van de TH Delft", in: http:/ /www.cihc.nl/26/ FmV_archief.

6 Secondary education, in which Latin and Greek are taught in addition to the regular curriculum. This preparatory training was mandatory for studying law. 
Hwa Hui took place in 2011, a century after its foundation. The association's very last act, a donation to the Foundation for Chinese Indonesian Heritage, was in full compliance with the statutory condition that a donation from the $\mathrm{CHH}$ could be destined only for an organization involved with Chinese from Indonesia.

After 1945 Chinese students, both in the Netherlands and in Indonesia, found themselves having to contend with a new situation. The Chinese had to reconsider their place in the new society of the Indonesian Republic. The turbulent years after 1945, the transfer of sovereignty in 1949, and the subsequent Assignment Agreement on Nationality (Rijkschroeff and Kwa 2011: 40-41), ${ }^{7}$ the growing anti-Chinese climate in the first Republican period, the increasing discrimination, the breach with the Netherlands in the late fifties, and, finally, the violence engendered by the coup of 1965 triggered flows of migration, the majority to the Netherlands. This time it was not only students who came to the Netherlands, but also families with children. Chinese parents, very concerned about their position and the very uncertain future in Indonesia, took the big step of leaving their homeland to seek safety and expecting to be able to build a better future for their family outside Indonesia. Leaving behind family, property, and other collateral, they arrived in the Netherlands as postcolonial migrants, either directly to the Netherlands or indirectly through other countries, often individually, sometimes in small migratory waves. Their motives for choosing the Netherlands were embedded in their colonial past, for instance, shared language, Dutch education, familiarity with Dutch culture, and the expectation that they would be able to build a new life in the Netherlands, as others who came before them had done.

In general they managed well, building a new, often simpler life. Finding a home, securing a job, becoming an independent entrepreneur, they found their way individually or with the help of family and friends. They made sure that their children would receive a good education, often one of the important reasons for migration. This independent and self-supporting attitude, without resorting to government aid or support, was one reason they went unnoticed by the Dutch society. Their situation was comparable to the good news that never reaches the newspapers.

Being inconspicuous and unnoticed, being neither a bother to nor a burden on the Dutch community, restricting themselves to contributing to Dutch society in a positive way, undeniably has had its good sides. However, the downside is the risk of the oblivion and obscurity which silence and invisibility might lead to.

\footnotetext{
7 At the transfer of sovereignty in 1949, the governments of Indonesia and the Netherlands agreed (Toescheidingsovereenkomst met Indonesië, 21-12-1949) that the inhabitants of Indonesia would be assigned either the Indonesian (Warga Negara Indonesia) or the Dutch nationality on the following criteria: 1) Persons with Dutch nationality could keep their Dutch nationality or opt for Indonesian nationality if they had been born in Indonesia and were older than $18 ; 2$ ) Dutch subjects without Dutch nationality were automatically assigned Indonesian nationality. The term of option ended 28-12-1951.
} 
PRESENT BUt NOT RETRACEABLE

Although there must be thousands of Peranakan Chinese residing in the Netherlands this particular Chinese group seems difficult to trace in the population from the former Dutch colonies. Whenever the Chinese from Indonesia are being discussed, the question which is often asked is: How many of them are there? It is a rational and legitimate question to which we were unable to find a clear answer, as will be shown below.

Our search on data on Peranakan Chinese who came to the Netherlands in the period after 1945 began with the question of whether such information exists and, if so, where it is to be found. The search has led us to review the publications on repatriation from Indonesia to the Netherlands and on minorities and migrants in the Netherlands, as well as to the studies of a few authors who have focused their research specifically on the Chinese from Indonesia. Among those in the latter category, Kees van Galen deserves special mention. In his thesis on the Chinese Students Association, the Chung Hwa Hui, he has made a methodical attempt to measure the number of Chinese from Indonesia (Van Galen 1989: 42-43).

\section{THE CRITERION OF NATIONALITY}

The data collected by the Central Bureau of Statistics (CBS) do not specify Chinese from Indonesia, since this government institution uses in its registration the criteria nationality and country of origin, not ethnicity (CBS 23-9-2015; Benton and Vermeulen 1987: 11).

However, nationality as a criterion, seems inadequate in the search for Peranakan Chinese who came from Indonesia after 1945, since their legal position before and after 1945 was a rather complex issue. Because of their legal status in the colonial period, the Chinese, as Dutch subjects (Nederlands onderdaan) in the Dutch East Indies, might belong to either the (large) group of Foreign Orientals with their assigned legal status (not equated with Europeans) or to the (small) group of Chinese Foreign Orientals who had individually acquired equal status with Europeans (gelijkgesteld). In the colonial legal system for Chinese being a Dutch subject, or accorded a legal position equal to that of Europeans, did not automatically mean the possession of Dutch nationality. Peranakan Chinese in the Dutch East Indies who had acquired the same legal status in the archipelago as the Dutch, remained Dutch subjects with a nonDutch nationality (Nederlands onderdaan, niet-Nederlander). After the transfer of sovereignty in 1949 and at the end of the term of option under the Assignment Agreement (1949-1951), they either had Dutch or Indonesian nationality.

Moreover, under statutory Chinese nationality law which was in force at the time, Peranakan Chinese with Indonesian nationality also had Chinese nationality, which meant they had dual nationality. Between 1960 and 1962, however, they were required to choose between these two. Those who did not renounce their Chinese nationality would, by law, lose their Indonesian 
nationality. ${ }^{8}$

At this moment we have no insight into whether and, if so, under which nationality - Dutch, Indonesian or Chinese - Peranakan Chinese were registered in the Netherlands before and after 1949. During the New Guinea conflict at the beginning of the sixties, Peranakan Chinese in the Netherlands could also be stateless.

Turning to the regulations for admission to the Netherlands for aliens, matters become more complicated, because here the criterion of ethnicity was applied. In the Netherlands, Chinese from Indonesia with a non-Dutch nationality (for example, Indonesian), were considered "aliens". The policy for the admission of aliens made an exception for the Chinese in general and for the Chinese from Indonesia in particular. Until 1980, Chinese in general (Chinese or people with Chinese national character) ${ }^{9}$ were placed in a separate category on the basis of their ethnicity. In that year, this distinction by ethnicity was removed "in order to avoid any suggestion that the Netherlands would discriminate in the admission of foreigners". However, these regulations, which were in force before 1980, did not apply to Peranakan Chinese from Indonesia (Groenendijk ${ }^{10}$ 1987: 92-94). In this admission policy, Peranakan Chinese proved to be the exception to the exception.

Likewise, the separate regulations governing the issuance of residence permits to "aliens of Chinese character", which were in effect until 1982, did not apply to Peranakan Chinese from Indonesia (Groenendijk 1987: 92-94).

These exemptions show what a highly complex situation has to be unraveled if we are to gain some insight into the difficulties and, probably in the impossibility, of obtaining reliable data on the basis of the nationality criterion, between 1945 and 1949, and after.

\section{THE CRITERION OF COUNTRY OF ORIGIN}

The country of origin appears to be another criterion which is inadequate for tracing the Peranakan Chinese, even though it concerns only one single country of origin: Indonesia. The large group of "repatriates" from Indonesia to the Netherlands between 1945 and 1963 consisted of many different ethnic groups. These people left Indonesia for the Netherlands for various reasons and at different points in time. Following the example of many authors, we use the collective term "repatriates" in this article to indicate these migrants,

\footnotetext{
8 The "Agreement on Dual Nationality between the Indonesian Republic and the People's Republic of China" became effective in January 1960. The period of duration of the agreement was two years. Its aim was that subjects of both countries (bipatrides) would renounce one of the two nationalities within the stated period; see the note on the application of the Nationality Law of the People's Republic of China of September 10, 1980 by the Municipal Register Amsterdam, 11-10-2000.

9 "personen van Chinese landaard" (C.A. Groenendijk 1987).

10 C.A. (Peter) Groenendijk, Em. Professor of the Sociology of Law at Radboud Universiteit Nijmegen was a specialist on (im)migration laws. His extensive research and publications cover the regulations of labour and asylum migration and the legal position of migrants in the Netherlands and in Europe.
} 
although, in the literature, there is no agreement on this term or on the people who might have been included in this category. Rijkschroeff and Kwa (2011) use "repatriates" to describe all people who left Indonesia for the Netherlands between 1945 and 1963, whereas Ellemers and Vaillant divide the whole group in Indo-Europeans (Indische Nederlanders) ${ }^{11}$ and repatriates. Peranakan Chinese would fall in the category of repatriates.

Rijkschroeff and Kwa (2011) distinguish four repatriation waves in the period 1945-1963. Their distinction is based on key political events which occurred during this period. They refer to the repatriates between 1945-1949 as "temporary repatriates", because the majority eventually returned to Indonesia. The people in the second wave (1950-1951), after the transfer of sovereignty, are called "permanent repatriates". The third wave of repatriation between 1952 and 1957 includes the Indo-Europeans, and the fourth and last wave in 1958-1963, prompted by the New Guinea conflict, involved the "spijtoptanten", people who regretted their choice of Indonesian nationality between 1949 and 1951. Peranakan Chinese would have found themselves in one of these four groups of repatriates, state Rijkschroeff and Kwa (2011: 26-27, 103-104).

Ellemers and Vaillant add a fifth group: The migrants between 1964 and 1980. Until 1968 this group of migrants consisted mainly of spijtoptanten and "socially Dutch people" (maatschappelijke Nederlanders). After 1968 the majority of this group was made up of Indonesians most of whom had been born in Indonesia. "Socially Dutch people" were those who automatically became Indonesian citizens after the transfer of sovereignty under the Assignment Agreement (Toescheidingsovereenkomst met Indonesie 21-12-1949). These people were historically and culturally strongly linked to the Dutch population, but were not able to prove their Dutch ties, one of the conditions of acceptance. They could not, for example, produce evidence of their descent from Dutch ancestors. Peranakan Chinese would have been strongly represented in this group of "socially Dutch people", although they did not meet the requirement of being of Dutch descent. Rijkschroeff has set the number of Peranakan Chinese who arrived in the Netherlands as "spijtoptanten" or "socially Dutch people" at 3,000, a count he bases on the number of visa applications (Rijkschroeff and Kwa 2011: 28-29, 82-83, 92, 102-104, 128, 138; Ellemers and Vaillant 1985: 41-42).

\section{THE CRITERIA OF ORIGIN AND ORIENTATION}

Ellemers and Vaillant (1985) apply two other criteria - those of origin and of orientation - to distinguish five categories within the group of repatriates from Indonesia since 1945. The first group consisted of repatriates in the narrower sense: People born and raised in Europe, with weaker ties to the Netherlands Indies than those in other categories would have had. The second group included the repatriates who, although of "pure" Dutch descent, 
were born and raised in the Dutch East Indies, and who had married IndoEuropean, Indo-Chinese or Indonesian women and who consequently felt strongly connected to their country of birth. The third and largest group was composed of the Indo-Europeans (people of mixed descent). The fourth group consisted of Indonesians who regarded themselves as Indo-Europeans (Indische Nederlanders), who had strong ties to the Dutch government and had subsequently settled in the Netherlands, as among them the Moluccans or Ambonese, the Minahasans or Menadonese, and the Timorese. Finally, the fifth and last group contained the Peranakan Chinese, especially those who were western-orientated and university graduates (Ellemers and Vaillant 1985: 17-18). These groups, which had links to the Netherlands in some way by origin or orientation, left Indonesia for the Netherlands in various periods between 1945 and 1980.

From these examples of the use of different categories, criteria, and definitions of the various groups of repatriates we are able to deduce with certainty that Peranakan Chinese could be found in more than one, if not in all, wave of repatriation and that they could be subsumed into one or more categories of repatriates. However, again it is virtually impossible to obtain reliable data on them. They are too well hidden in the entire population of repatriates and migrants.

The literature on minorities policy, which was initiated by the government in the nineteen-eighties, barely mentions Chinese from Indonesia. Peranakan Chinese did not qualify to be included in this sort of policy because they did not meet at least one requirement for being classified as an "ethnic minority". To be acknowledged as such, members of that minority should have a "predominantly low socio-economic position" (Entzinger 1984: 28). The qualifications of most Peranakans made it unlikely that a majority would have satisfied the condition of being socio-economically disadvantaged (Benton and Vermeulen 1987: 18). Nevertheless, they are - as a part of the Chinese community as a whole - included in the policy for minorities. The Consultative Body for Chinese (Inspraakorgaan Chinezen, IOC) acts on behalf of the entire Chinese community as the sole spokesperson to the government (Rijkschroeff, The, and Verlaan 2011: 97). Groenendijk mentions another possibility which might explain the exclusion of Chinese from the minorities policy. When the foundations of this policy were laid down in 1980, the attention paid to the Chinese population in general had a "predominantly restrictive rather than facilitating purport" (Groenendijk 1987: 114).

In Verwey-Jonker's work "Non-western immigrants in the Netherlands" (Allochtonen in Nederland), commissioned by the Department of Cultural Affairs, Recreation, and Social Welfare, the authors Vellinga and Wolters explicitly mention that their chapter on "The Chinese" only covered Chinese people who had come directly from China. "The group of Indonesian origin - the Indo-Chinese or Peranakan Chinese, comprising thousands of people, were not to be taken into account" (Vellinga and Wouters in Verwey-Jonker 1973: 219). Their reasons for this exclusion were: their origin; their cultural 
orientation towards the Netherlands; their predominant Dutch nationality; and their absence of contact with Chinese who had come directly from China.

Institutions which engage with minorities in the Netherlands also often overlook the Chinese or do not include them in their studies. Such disregard is reflected when the Central Bureau for Genealogy concluded its series Voorouders van verre (Distant ancestors), research guides for genealogical research designed for minorities, with the issue of Part 7: "Chinese roots". At the 2011 presentation of this research guide for all Chinese people with Chinese ancestors residing in the Netherlands it was admitted ${ }^{12}$ that, after the six publications for the Moluccan, Moroccan, Turkish, Surinamese, Antillean minorities and the Dutch Eurasians, at the last moment realization dawned that the Chinese population had been forgotten. "Chinese roots", the unplanned tailpiece, focuses on genealogical research mainly of the Chinese from China. One page is dedicated to the Peranakan Chinese from Indonesia (Kuiken 2011: 25-26).

\section{QUANTIFYING THE GROUP}

\section{Estimates of repatriates and Peranakan Chinese}

The migration from Indonesia to the Netherlands after World War II has never been completely registered. To complicate matters, quite a number of people were never registered, for instance, those who managed to find housing either by themselves or with the help of relatives or friends. As a result, there can be large variations in the given data. Ellemers and Vailant observe that the most elementary and basic facts and data, such as numbers and ratios, are lacking (Ellemers and Vaillant 1985: 11, 38, 53-54). In their study on population groups between 1945 and 1980 (Dutch Eurasians and the repatriates who had left Indonesia in waves), they could only produce an approximate number of repatriates, namely: about 200,000 to 250,000. The Central Bureau of Statistics followed with a fairly close estimate of 255,000 people, while the Central Committee for Christian and Private Initiative for the Care of Repatriates (CCKP, Centraal Comité voor Kerkelijk en Particulier Inititiatief) ${ }^{13}$ gave 284,000 people as an indication. The CCKP's aid-assistance data have been frequently used by researchers ((Ellemers and Vaillant 1985: 50-55; Rijkschroeff and Kwa 2011: 26). For the numbers of Peranakan Chinese during the repatriation period, we have to make do with the earlier mentioned number of 3,000 Peranakans as "spijtoptanten" and "socially Dutch people".

\section{Estimates of Chinese and Peranakan Chinese}

In 1987 Benton and Vermeulen produced an overview of the estimated numbers of the various Chinese groups in the Netherlands. As others before

12 Booklaunch 15-6-2011 Central Bureau for Genealogy-The Hague, attended by P. TjiookLiem.

13 The CCKP, a central organization for social welfare and aid, began work around 1950 at the governments' instigation. It contributed to the aid and relief for spijtoptanten to a large extent. Its work ended in 1968 (Rijkschroeff and Kwa 2011: 108). 
them have done, they also note that it was very difficult to make reliable estimates. Depending on the source, the total number of Chinese in the Netherlands, including the Chinese from Indonesia, could vary from 45,000 to over 55,000. The estimates supplied by such Dutch sources as the CBS and the police $(20,000)$ differed significantly from the more realistically considered figures supplied by the Chinese community itself and those supplied by the Taiwanese government. The latter's estimates were higher (Benton and Vermeulen 1987: 9-11). Meeuwse (2000: 14) estimates that there were about 100,000 ethnic Chinese living in the Netherlands.

In 1989 Willems and Cottaar (1989) thought that the total number of Chinese in the Netherlands, including those from Indonesia, was some 45,000 people. The largest group was formed by the approximately 30,000-40,000 Chinese who came to the Netherlands, mainly between 1946 and 1987, for socio-economic reasons. The majority came from China or Hong Kong, with a smaller number from Singapore, Malaysia, Taiwan, and Macao. Most of them worked in Chinese or Chinese-Indies restaurants. In terms of numbers, they were followed by the 6,000 to 8,000 Chinese from Indonesia, who migrated around the time of the independence of Indonesia or sometime after. In the third place were the 3,000 to 4,000 Surinamese-Chinese, who migrated after Suriname's independence in 1975, and finally there were the 3,000 Vietnamese Chinese who migrated for political reasons and who were counted among the boat refugees (Willems and Cottaar 1989: 123).

For the numbers of Peranakan Chinese in the pre-World War II period and thereafter, we have to rely on the numbers of the student population in Van Galen's thesis and his count in 1984. Other data are not available.

In 1911-1913 there were approximately 60 students. Around 1920 this number had grown to 65 and in 1930 there were around 150 Peranakans in the Netherlands. One hundred and fifteen of them attended university or had acquired a university degree, twenty-five were secondary school pupils or were following other non-academic courses. The remaining ten were married women. During World War II there were still 130 Peranakans residing in the Netherlands. Between 1946 and 1949 their number increased to approximately 500. The majority was made up of new students, the rest were graduates who had found jobs in the Netherlands. In 1957 Van Galen estimated the number of Peranakans at 1,400, of whom 1,000 were students. A new influx between 1967 and 1970 raised the number to a few thousand people (Van Galen 1989: 4243). In 1984 Van Galen estimated the number of Peranakan-Chinese at around 6,750 . To reach this outcome he used the following random methodology:

A list of Peranakan names (generally Hokkien) was compiled on the basis of the names he found in the Chung Hwa Hui archives and in a number of books on Peranakans in Indonesia. For the cities of Amsterdam, Amstelveen, Rotterdam, The Hague, Rijswijk, Utrecht, Leiden, Delft, Eindhoven, and Nijmegen, he then counted the number of telephone connections registered to those names. On the basis of the (most common) surname, Tan, an estimate was made of the number of Peranakans listed in the telephone-directories of 83 towns and villages spread 
over the Netherlands. A correction was then applied, as some names might have belonged to other Chinese or even to Dutch people. On the basis of demographic data from the Central Bureau of Statistics, these numbers were systematized and correlated to the number of the total population of each city or town surveyed, in relation to the number per province. Taking into account the relative size of the Peranakans' percentage in proportion to the size of the city surveyed, the percentage of non-existent or ex-directory telephone connections and the number of people per telephone connection, an estimate was made for the entire country. The outcome of this was 6,750 Peranakans residing in the Netherlands. (Van Galen 1987: 146, note 4; 1989: 43.)

According to Rijkschroeff, by 2010 the number of migrated Peranakan Chinese had grown from 6,000 to 18,000 (Rijkschroeff, The, and Verlaan 2010: VII). Estimates by Oostindie in the same year range from 20,000 to 40,000 (Oostindie 2010: 29).

We cannot but concede that - on the basis of the available literature and notwithstanding their long historical ties with the Dutch and the Netherlands Chinese from Indonesia are difficult to retrace both in government reports and policies and in publications by researchers and institutions. Several reasons or causes have been put forward to explain why they, as a group, have not been taken into account or have been excluded. On account of the lack of reliable data, quantification was only possible by making a rough estimate. Although they are present in many walks of life, the scant attention they receive in comparison with other minority groups, means that they are barely visible.

\section{THE DEVELOPMENT OF THE CONCEPT OF HERITAGE}

The concept of heritage has evolved over time. Initially it had legal connotations which were closely linked to the law of inheritance. "Heritage" literally meant an estate possessed by hereditary right which had been or would be bequeathed to succeeding generation(s). This legacy was originally referred to as the "inalienable goods to be passed on from generation to generation, often from father to son". These were goods as well as cultural and material achievements which were transferred within the family by the older to the younger generation. Since the preservation of this heritage was essential to the enduring continuance of the family, transfers of inheritance were safeguarded and protected by various legal regulations. Examples include certain rights and privileges held by aristocratic families and farmland for farmers.

At the end of the eighteenth century, "heritage" as a legal concept protecting family property had lost most of its relevance. The importance of the family as a unit decreased with respect to goods and property, whereas the interests of individual beneficiaries increased. The explanation, says Peter van den Berg, ${ }^{14}$ can be sought in socio-economic circumstances, for instance,

14 Peter A.J. van den Berg studied law and history. He is a senior lecturer at the Faculty of Law, Universiteit Groningen. In his chapter "Erfgoed; De juridische herkomst van een metafoor" (Heritage; The legal origin of a metaphor), he deals with the legal foundations of the concept of heritage. 
greater prosperity resulting from increased productivity in agriculture and the growing importance of trade. Consequently, the importance of acquiring property through inheritance decreased in comparison to obtaining property and goods through independent acquisition. In other words, the individualization of the concept of ownership was growing at the expense of the significance of family property (Van den Berg 2007: 21-43).

The French Revolution (1789-1799) also marked the end of the ubiquitous representation of church, nobility, and royalty. Heritage in the form of antiques, works of art, and monuments, which were previously enjoyed by a small privileged group, fell to the state and became "the inheritance of all". This heritage became the responsibility of the state and therefore deserved to be preserved and maintained at the state's expense. With its transition from the private-legal to the cultural-public domain, heritage was transformed from an individual into a collective category, at the same time laying a claim on the government to preserve and protect it.

This development occurred some time later in the Netherlands where the term "cultural heritage" only came into use in the nineteenth century, when it was feared that historically important artworks were in danger of disappearing from the country and that objects and pieces of art would not be given the care, restoration, and preservation they deserved. Clearance sales and the neglect of national treasures had to be prevented (Grijzenhout ${ }^{15}$ 2007: 5-6).

\section{BROADENING THE SCOPE}

In more recent time, the concept of heritage itself has undergone a development which has broadened its scope. Heritage not only includes items qualified for museums and libraries, such as works of arts and science, but also buildings, landscapes, and nature. "Cultural heritage" is the new term adopted in this broader scope which includes everything that deserves protection and preservation (Grijzenhout 2007: 1-30; Oosterbaan ${ }^{16} 2014$ : 78-79). Consequently, the concept of cultural heritage has acquired a metaphorical meaning that is universally recognizable, consistent and, therefore, convincing and inspiring. The claim for the protection of the cultural heritage has been expanded from national governments to international organizations such as UNESCO. The World Heritage List of the UNESCO requires that unique, and sometimes endangered, heritage should be protected.

15 Frans Grijzenhout is Professor of Cultural Heritage, Restoration, and Preservation at Universiteit van Amsterdam. In the volume Erfgoed; De geschiedenis van een begrip (Heritage, the history of a concept), several aspects of heritage are being discussed. Grijzenhouts' publications range from studies on the history of notions on cultural heritage up to the relation between the arts and politics, especially in the eighteenth and nineteenth century.

16 Warna Oosterbaan, sociologist and journalist, was Professor of Journalism and Society at Erasmus Universiteit Rotterdam. In 2011 he was commissioned by NWO (De Nederlandse Organisatie voor Wetenschappelijk Onderzoek/The Netherlands Organisation for Scientific Research) to write about the results of an extensive researchprogram called "Cultural Dynamics" (2008-2014). In this research program the keyword was "cultural heritage" as a dynamic concept, which is continuously reproduced, re-interpreted, and appropriated. 
The scope was enlarged even further with the addition of the distinction between tangible and intangible heritage. In the first category, tangible memories of the past would be represented by objects which are collected by museums, libraries, and other institutions and organizations. "Intangible" heritage initially referred to the spiritual heritage of a thinker or an artist, to the traditions of the Christian faith, the traditions within a family, as well as to the set of norms and values which characterizes a culture (Grijzenhout 2007: 1). Now the concept has developed further. In Frijhoff' ${ }^{17}$ interpretation of intangible heritage "tradition" assumes a prominent place. Although his interpretation comes from the religious, specifically Christian, tradition, it contains two interesting aspects which might be useful in today's discussion about intangible heritage. The first aspect is the idea that the meaning of the spiritual heritage of a group relates not only to the past but also to the future. The spiritual "heritage of peoples" should not only be accepted but it should be managed, applied, and propagated as well. It should also serve as a source of inspiration, open to new contributions by later generations. The second aspect concerns the community or group which is felt to have a certain right to exist. As a group, it should own a shared story about itself to serve as a mutual guideline providing internal cohesion and external identity. As traditions are considered to be the decisive element in the group's sense of identity, the story takes shape within the tradition of that community (Frijhoff 2007: 45-56). Within this idea of intangible heritage closely linked to tradition and functioning as a source of inspiration for a collective group identity, a positive and offensive attitude to spiritual heritage can be detected. At the present time, the stance towards heritage is primarily one of concern and defence. Today the emphasis is on preservation rather than inspiration.

Until a few decades ago, heritage was mainly seen as a collection of important items belonging to or associated with a higher social class. This was attributable to the fact that previously only official and political events were regarded as history. The focus was then on history-makers such as kings, politicians, and rulers who were, according to the prevailing view, those who determined the course of history. The emergence of the industrial society in the nineteenth century brought changes in the social hierarchy. As new social classes, including the working class, gained a place in society, the need arose to understand these changes. Official history could not offer this understanding and insight. Social history, which was a relatively new branch of sociology closely linked to economic history, took a greater interest in the history of these large, new and previously obscure social classes. Consequently, in socio-historical research, the need for a better understanding of the societal developments was met, enabling research on trends and systems in order to reveal the big picture in history. The area of social history research can be defined as the daily life of a country's inhabitants in the past (Duyvendak and

17 Willem Frijhoff is Professor of the History of the Modern Era at Vrije Universiteit Amsterdam. His research concerns historical forms and processes of cultural transmission and forms of religious perception. 
Kooy $\left.{ }^{18} 1992: 1-7\right)$. In this fashion, the concepts of history and heritage were socialized and democratized.

This development is particularly important to the role of oral history in the collection of intangible heritage. Oral history is concerned with the relationship between official history as recorded in books, and individual memory and experience. For migrants who have left their country, their home and property, the largest part of their heritage consists of whatever they have managed to bring with them in their migration. Generally speaking, they have had to leave most, if not all, of their tangible heritage behind. By telling and recording their stories and memories the past can be preserved, events and experiences can be contextualized, and sometimes might offer essential additions to the official history. In this respect, migrant interviewees as "storytellers" act as bearers of intangible heritage, as bearers of history.

\section{HERITAGE TODAY: A FOOTHOLD IN A CHANGING WORLD?}

Heritage - a term with many meanings - is currently a topic of great interest. It appears in various publications and often springs readily to the lips of politicians, museum directors, historians and others. The word is very broadly interpreted as we have seen and, since people work in numerous areas of heritage, it is sometimes referred to as a growth sector or as a heritage industry.

According to Warna Oosterbaan, this increased interest in heritage has its origin in the fear that "our culture" and "our identity" will be lost in the maelstrom of rapid changes ushered in by globalization and individualization, new phenomena which threaten to dislodge former relationships. Inevitably, these changes are taking effect in the population structure of an immigration country such as the Netherlands, where there have been influxes of large groups of people with different cultural backgrounds. A need to accommodate these new cultures is created when these groups remain permanently. It is felt that the historical identity of the Netherlands is not a calm and undisturbed possession any more, as it does not offer a guarantee for social cohesion. All the more precarious because, at the same time, the formation of a new identity is still at an uncertain stage. There is a feeling of being caught in a "social crisis" in the own society which has "become pluralistic and multicultural to an unprecedented degree". Almost all Western societies seem to have lost their "self-confidence". In a time of rapid changes, heritage in the Netherlands might be the beacon, the basis to hold on to. This argument was the reason why a comprehensive investigation into what is called "cultural dynamics" was initiated in the Netherlands from 2008 to 2014. In this study, in which cultural heritage played a key role, culture, identity, and history have emerged as important components in the concept of heritage (Oosterbaan 2014: 9-10).

18 P. (Pim) Kooy. Em. Professor of Economic and Social History at Universiteit Groningen. His successor is M.G.J. (Maarten) Duijvendak, Professor of Economic, Social and Regional History. 
What can heritage mean to Migrants Such as the Peranakan Chinese?

One definition of heritage is that it is something which is allotted to us from the past, assigning us to do something with it and pass it on to those after us. Heritage can be something to be proud of, but it can also raise painful memories. It is associated with a period that lies behind us and has been completed, or with a culture that no longer exists but should, somehow, be retained or preserved. We should avoid suggesting it is everything that is old or traditional. Rather, it is a selection of tangible and intangible effects with a great power of expression, selected and purposely chosen with a view to strengthening the desired collective identity of the group. Heritage not only speaks the language of the past, but also shows what has shaped us into who we are and is in this way regarded as a means to represent social identity. The connection between heritage and identity is a strong one (Oosterbaan 2014: 11).

For people living in their own country, such as the Dutch in the Netherlands, the overwhelming meaning of heritage today seems to be centered on the fear of loss of culture and history, followed by efforts to preserve the relics of the past as a present foothold and also as a legacy for future generations. However, they do not have to worry about two important and integral parts of their heritage, which are considered necessary to internal cohesion and at the same time provide external identity: a collective identity and a "shared story about themselves".

Building on this discussion, we can try to formulate an idea of what heritage can mean for migrants such as the Peranakan Chinese. Their situation in their new country is entirely different from that of the regular inhabitants. Having had to leave most of their tangible heritage behind in their former homeland, they have already experienced the sense of loss, a deprivation which they have probably accepted as an inevitable consequence of settling in a different culture. Moreover, they will have prepared themselves for the process of adaptation and integration during which they will not always be able to hold on to what they have brought with them as their heritage, for instance, their culture and identity. In time, all this might slowly been drained of most of its significance and meaning, not only because of rapidly changing times, but also as a result of being cut off from the life and culture which have been left behind, a continuous disconnectedness resulting from living in another culture. Under such circumstances, Peranakan identity will become fluid and elastic and it will become more and more difficult to pass on.

Therefore, what elements can be considered to be most meaningful for migrants to preserve? If there is important tangible heritage which they have managed to bring with them, this should be preserved. But, looking at migrants as bearers of history, it is probably their intangible heritage which we should cherish most and therefore must record. After all, this heritage not only represents their own personal history but, at the same time, it is an undeniable part of the group's history. It can contribute to constructing the shared story, which will give the group its face and the needed collective 
identity. This shared story, best coined ${ }^{19}$ as the "group's biography", will probably be the most valuable heritage to preserve and pass on.

Now after seventy postcolonial years, Peranakan Chinese are in the process of sinking into oblivion, of dissipating as a group. They are, as said and concluded earlier, barely visible in Dutch society, almost untraceable in figures and publications on repatriates and minorities in the Netherlands. So far, their past has been neither sufficiently told or heard nor has it been recorded. The upshot is that it cannot be understood, not even by their own offspring. Without knowledge about their (grand)parents' history, the younger generations will be missing the context and background which will lead to understanding.

It should be realized that the Peranakan Chinese history is definitely not the same as those of other repatriate-groups from the Dutch East Indies. Although all these groups share the Malay Archipelago as their country of origin, the Netherlands as their future homeland, and familiarity with the Dutch culture and language, among these groups the Peranakan story stands out on account of its difference. Peranakan Chinese lives in the Dutch East Indies/Indonesia, their migration motives, their integration in the Netherlands were often influenced and determined by such factors as ethnicity and their specific socio-economic position, which marked their place in society.

Should the Peranakan story - our shared story - be considered to be important heritage which is worth saving and recording, one of the consequences will be the group's stepping out of the shadows and shrugging off obscurity. The alternative is to remain inconspicuous and unnoticed, content that new generations will continue to be more or less ignorant of their own history. Such a decision will leave us with no history at all, because that history will soon be lost and forgotten and it will be us who have failed to preserve it.

\section{The Chinese Indonesian Heritage Center (2011-2016)}

In the past five years the CIHC has been involved in various areas in pursuit of its main goal, which is collecting heritage material of the Chinese from Indonesia to prevent it from being lost beyond retrieval. For this purpose, it has worked together with the University Library of Leiden, an institute which, besides its own collection, also manages the collection of the KITLV. Since 2013 the CIHC has been compiling a collection of intangible heritage in the form of interviews of first-generation Peranakans in the Netherlands. The Mongesch ${ }^{20}$ team is engaged in and committed to this oral history project.

We realize that it is not possible to collect Peranakan Chinese heritage without providing the group concerned with proper information, especially when, for too long too little attention has been paid to its own history. Creation of awareness and appreciation of that history are essential elements in this information. This is the reason that the CIHC organizes Open Days. The first 
took place in 2012. As there proved to be enormous interest in this event, a second Open Day was held two years later. The presentations at the most recent Open Day on June 24, 2016, covered important periods in our history in Indonesia and the Netherlands. The formula of informing the public about the many aspects of its own history in an accessible way has turned out to be successful. Interest is also growing among the younger generation, among whom their (grand-)parents' history is often unknown.

For donations of heritage material which is not suitable to the collection of the KITLV or to the University Library of Leiden, the CIHC works together with the Museum of Ethnology in Leiden. In 2015 a joint event was organized with the museum, involving two main elements: the opening of the Peranakan exhibition in the Museum of Ethnology, the very first in Dutch museum history and the presentation of a special donation to the CIHC by Mr Siem Tjong Han. The theme of the Peranakan exhibition was Peranakan weddings and marriages in general and it was centred on the antique wedding dress donated to the museum by Mr. Kan Sioe Yao. Mr Siem's donation included a collection of 125 postal items, which were in use for correspondence among the Chinese in the Dutch East Indies between 1865 and 1949. Again, interest in this event was significant.

Besides organizing these Open Days to appeal to a wider audience, the CIHC compiles fragments of personal history, memories of special moments in a person's life, and publishes them on its website under the heading "Snapshots with Stories". After translation into English, they also appear on the CIHC Facebook page. This is the way the CIHC tackles the task of making room for the small, personal histories. Furthermore, facts on cultural issues and traditions are regularly featured in the website's section "Traditions and Culture". The newsletters, issued bi-annually, are intended to keep interested parties informed of ongoing activities, as well as recent initiatives.

Another aspect which has the full attention of the CIHC and the KITLV is the encouragement of research. The material compiled by the CIHC team for the aforementioned Mongesch Oral History Project will be a unique source for research. In 2015, the first CIHC-KITLV fellowship was granted to Mr. F.X. Harsono, a renowned Chinese Indonesian artist-cum-researcher and a Prince Claus Laureate in 2014, to conduct research in the Netherlands into violence perpetrated against Chinese in the post-war years of 1948-1949. This is a recurring theme in his artwork. Organizing lectures and presentations, writing scientific articles, for instance for this special issue of Wacana, Journal of the Humanities of Indonesia, are integral parts of CIHC activities. All the CIHC's activities are supported by the KITLV and the Foundation for Chinese Indonesian Heritage.

The CIHC will continue along the same path: collecting heritage material, informing older and younger Peranakans, motivating commitment, and stimulating research. In recent years, the CIHC, in conjunction with the KITLV and the Foundation for Chinese Indonesian Heritage has managed to build a solid foundation from which further initiatives can be launched. Research 
and publication of our "shared story", in particular the migration history, is considered a heritage which is essential to pass on. It connects first generation Peranakan Chinese as postcolonial migrants to the generations of their children and grandchildren. A well-documented legacy which is absorbing for and accessible to a wide readership is, therefore, a goal which is well worth pursuing. On its own, the dedication of the CIHC team will not be enough. This undeniably ambitious goal cannot be achieved without the mental and financial support of the own community, and others who are interested.

\section{REFERENCES}

Benton, Gregor and Hans Vermeulen (ed.). 1987. De Chinezen; Migranten in de Nederlandse samenleving. Muiderberg: Coutinho.

Berg, P.A.J. van den. 2007. "Erfgoed; De juridische herkomst van een metafoor", in: F. Grijzenhout (ed.), Erfgoed; De geschiedenis van een begrip, pp. 21-43. Amsterdam: Amsterdam University Press.

Bosma, Ulbe, Jan Lucassen, and Gert Oostindie (eds). 2012. Postcolonial migrants and identity politics, Europe, Russia, Japan and the United States in comparison. New York/Oxford: Berghahn Books.

Duyvendak, Maarten and Pim Kooy. 1992. Sociale geschiedenis; Theorie en thema's. Assen/Maastricht: Van Gorcum.

Ellemers, J.E. and R.E.F. Vaillant. 1985. Indische Nederlanders en gerepatrieerden. Muiderberg: Coutinho.

Entzinger, H.B. 1984. Het minderhedenbeleid. Amsterdam: Boom. PhD thesis, Leiden University.

Frijhoff, W. 2007. "Hemels erfgoed; Een reflectie", in: F. Grijzenhout (ed.), Erfgoed; De geschiedenis van een begrip, pp. 45-56. Amsterdam: Amsterdam University Press.

Fromberg, P.H. 1911. De Chineesche beweging op Java. Amsterdam: Elsevier.

Galen, Kees van. 1987. “Dorp zonder naam; de Chinezen uit Indonesië”, in: G. Benton and H. Vermeulen (eds), De Chinezen; Migranten in de Nederlandse samenleving, pp. 132-146. Muiderberg: Coutinho.

Galen, Kees van. 1989. “Geschiedenis van de Chung Hwa Hui (1911-1962), Indo-Chinese studenten en Peranakan politiek in Nederland". Master thesis, Universiteit van Amsterdam.

Grijzenhout, Frans (ed.). 2007. Erfgoed, de geschiedenis van een begrip. Amsterdam: Amsterdam University Press.

Groenendijk, K. [C.A.]. 1987. “De rechtspositie van Chinezen in Nederland; Van achterstelling naar formele gelijkheid", in: G. Benton and H. Vermeulen (eds), De Chinezen; Migranten in de Nederlandse samenleving, pp. 85-117. Muiderberg: Coutinho.

Kuiken, Kees. 2011. Chinese roots; Voorouders van verre; Deel 7-China. The Hague: Centraal Bureau voor Genealogie.

Meeuwse, Karina. 2000. Het huis van Han. Utrecht: Bruna.

Meijer, Hans. 1992. Den Haag-Djakarta; De Nederlands-Indonesische betrekkingen 1950-1962. Utrecht: Spectrum. 
Oosterbaan, Warna. 2014. Ons erf, identiteit, erfgoed en culturele dynamiek. Amsterdam: De Bezige Bij.

Oostindie, Gert. 2010. Postcolonial Netherlands, sixty-five years of forgetting, commemorating, silencing. Amsterdam: Amsterdam University Press.

Rijkschroeff, B. and G.A. Kwa. 2011. Spijtoptanten en achterblijvers. The Hague: Ons Bos.

Rijkschroeff, B., Paul The Gwan Tjaij, and Antoon Verlaan. 2010. Indonesische Chinezen in Nederland. Amsterdam: SWP.

Tjiook-Liem, Patricia. 2009. De rechtspositie der Chinezen in Nederlands-Indië 1848-1942. Leiden: Leiden University Press. [PhD thesis, Universiteit Leiden.]

Verwey-Jonker, H. (ed.). 1973. Allochtonen in Nederland. Den Haag: Ministerie van Cultuur, Recreatie en Maatschappelijk Werk.

Willems, W. and A. Cottaar. 1989. Het beeld van Nederland; Hoe zien Molukkers, Chinezen, woonwagenbewoners en Turken de Nederlanders en zichzelf. Baarn: Ambo, Den Haag: NOVIB. 